\title{
Postanowienia Soboru Stu Rozdziałów z zakresu teologii praktycznej
}

\author{
ks. Karol Wilkiel \\ Katolicki Uniwersytet Lubelski, Instytut Ekumeniczny, Polska \\ ORCID: 0000-0001-6292-3167 \\ karol.wilkiel@gmail.com
}

rev. K. Wilkiel, Decisions of the Stoglavy Synod regarding practical theology, Elpis, 22 2020: 45-54.

\begin{abstract}
The article concerns historical conditions of one of the key councils which took place in Russian Orthodox Church. It was convened by Tsar Ivan IV at the beginning of 1551 in Moscow, and it was signed up in history under the name The Stoglavy Synod. The name of the Council follows its decisions - a final document which contained one hundred chapters. This article is the analysis of its decisions, concerning practical theology, as well as problems with conduction of liturgy, faced by the Russian Orthodox Church in 16 th century.

Streszczenie: Artykuł podejmuje analizę wybranych postanowień jednego z ważniejszych soborów, który odbył się w ruskiej cerkwi. Został zwołany przez cara Iwana IV na początku 1551 r. w Moskwie i przeszedł do historii pod nazwą Sobór Stu Rozdziałów. Nazwa soboru wynika z jego postanowień - dokumentu końcowego, który zawierał sto artykułów (rozdziałów). Niniejszy artykuł przedstawia analizę postanowień Soboru Stu Rozdziałów, które dotyczą teologii praktycznej. Owe postanowienia ukazują również problemy praktyki liturgicznej, z jakimi borykała się ruska cerkiew w XVI w.
\end{abstract}

Keywords: The Orthodox Church, history of church, council, Russian Orthodox Church

Słowa kluczowe: Prawosławie, historia kościoła, sobór, Rosyjski Kościół Prawosławny

Sobór Stu Rozdziałów, który odbył się w Moskwie w 1551 r. był to tzw. Sobór Ziemski, ponieważ podejmowano na nim decyzje nie tylko dotyczące Cerkwi, ale również i państwa. Inicjatorem zwołania soboru był car Iwan IV Groźny ${ }^{1}$ w porozumieniu z metropolitą moskiewskim Makarym. W soborze uczestniczyli dwaj arcybiskupi, siedmiu biskupów, przedstawiciele monasterów, niższego duchowieństwa, bojarów oraz wiernych. Główną przyczyną zwołania soboru był nieporządek w liturgicznym i duchowym życiu Cerkwi na Rusi. Po upadku Konstantynopola w 1453 r. władcy moskiewscy zaczęli postrzegać siebie jako następców bizantyńskich imperatorów. Zwołany przez cara sobór miał celu ukazanie bizantyńskiej symbiozy państwa i Cerkwi (Bułgakow, 1870, s. 219-220)2.

Niniejszy artykuł poświęcony jest analizie postanowień Soboru Stu Rozdziałów dotyczących teologii praktycznej. Jednym z powodów zwołania Soboru Stu Rozdziałów był nieporządek w życiu liturgicznym Cerkwi. Problem ujednolicenia rytów cerkiewnych okazał się jedną z najbardziej złożonych kwestii, z jakimi miał do

\footnotetext{
Iwan IV Groźny - urodzony 25 sierpnia 1530 r. w miejscowości Kołomienskoje, zmarł 18 marca 1584 r. w Moskwie. Syn Wasyla III i Heleny Glińskiej. Od 4 grudnia 1533 r. Wielki Książę Moskiewski. Był on pierwszym władcą Rosji, który koronował się na cara. Owo wydarzenie miało miejsce 16 stycznia $1547 \mathrm{r}$. Władzę sprawował do śmierci, tj. do $1584 \mathrm{r}$. (Florja, 2010, s. 628-629).

2 Więcej na temat historii Soboru Stu Rozdziałów, Zob. (Wilkiel, 2019, s. 27)
}

czynienia sobór. Ks. Aleksander Schmemann twierdzi, iż sens Soboru Stu Rozdziałów polega na stopniowym odrzucaniu tradycji greckich i przeciwstawiania prawosławiu ruskiemu - prawosławia greckiego, co nastapiło po uwolnieniu się z kanonicznej zależności od Greków. Ojciec Aleksander dodaje, iż Iwan IV Groźny nie był wielbicielem „wiary greckiej”, a przejawiał skłonności do wpływów napływających z Zachodu (Schmemann, s. 314-315).

Poniżej przedstawiona będzie analiza wybranych rozdziałów (gław) dotyczących teologii praktycznej.

\section{Gtawa 7}

W rozdziale 7 Stogława (Stoglav", 1862, s. 83-86) kontynuowana (rozpoczęta była w gławie 6) jest odpowiedź na pierwsze pytanie cara ${ }^{3}$. Rozdział 7 postanowień soborowych poświęcony jest określeniu momentu rozpoczęcia bicia w cerkiewne dzwony. Dzwon cerkiewny miał obwieszczać wiernym o początku nabożeństwa w cerkwi, a faktycznie bywało tak, że dzwoniono nie na czas. Ustaw $^{4}$, którym posługiwała się Cerkiew, przyszedł na Ruś

\footnotetext{
3 Treść pytania 1: „O dzwonach i śpiewie w Cerkwiach, zgodnie z regułą cerkiewną; o powołaniu starostów kapłańskich; o celu tego powołania". (Bočkarev, 1906, s. 42)

4 Ustaw (Reguła liturgiczna, Typikon - księga zawierająca reguły) reguła dotycząca nabożeństw i życia liturgicznego. Określenia tyczą się również reguł monasterskich. Zbiór reguł cerkiewnych zawartych
} 
z Bizancjum. Początkowo funkcjonowały następujące reguły: Typikon Wielkiej Cerkwi i Typikon Studyjski. Jednak ostatecznie pojawiły się również reguły innych klasztorów, w szczególności Jerozolimskiego ${ }^{5}$, który przyjął się jako ostateczny i do dzisiaj funkcjonuje w praktyce liturgicznej Polskiego Autokefalicznego Kościoła Prawosławnego.

Sobór postanowił, w jakim czasie należy dzwonić (a co za tym idzie - rozpocząc nabożeństwa) na nabożeństwa niedzielne, codzienne, sobotnie, święta z liczby dwunastu, dzień śww. ap. Piotra i Pawła oraz w dni, kiedy przypadają święta mniejsze (Stoglav", 1862, s. 84).

Pomimo tego, że Stogław odsyła czytelnika tylko do Typikonów Studyjskiego i Wielkiej Cerkwi, to faktycznie reguły przytaczane w omawianej gławie były wzięte z Ustawu Jerozolimskiego. W 7 gławie Stogława, mamy do czynienia z przyjętymi zmianami, które nakreślił metropolita Ioasaf. W tym wypadku chodziło o możliwość przeniesienia nabożeństw na inną datę, jeśli wymagały tego uwarunkowania państwowe. Miało to miejsce przede wszystkim w sytuacjach, kiedy car wyjeżdżał na wyprawę wojenną. Oprócz tego, dzięki wprowadzonemu prawu skorzystali również handlarze oraz ludzie chorujący (Gorskij, A. (red.), 1985, s. 432-433).

\section{Gtawa 8}

8 gława (Stoglav", 1862, s. 86-88) stanowi odpowiedź na carskie pytanie dotyczące porządku nabożeństw. Są $\mathrm{w}$ niej zawarte pouczenia związane $\mathrm{z}$ carskimi pytaniami

\footnotetext{
w księdze Typikon - czyli ustaw, dzieli się na dwie części: pierwsza - dotycząca porządku nabożeństw, oraz druga - zawierająca dyscyplinę liturgiczną. Pierwsza część zajmuje się przedstawieniem porządku nabożeństw, druga zaś koncentruje swoją uwagę na postach, zakazach i nakazach dotyczących sprawowania nabożeństw, w szczególności Boskiej Liturgii. Jedną z cech typikonu jest powiązanie porządku nabożeństw, życia liturgicznego oraz sposobu odprawiania nabożeństw z zasadami określającymi monasterskie życie wspólnotowe. Kiedy wgłębimy się w współczesne redakcje typikonu, zauważymy scalania owych dwóch przejawów życia Cerkwi, m.in. poprzez umieszczanie $\mathrm{w}$ tekstach dotyczących celebry nabożeństw wzmianek odnoszących się do praktyk monasterskich nie związanych ściśle z nabożeństwem, a określających np. pory snu czy też jakie pokarmy można spożywać w danym dniu. Opracowując współczesne Typikony, autorzy opierali się na monasterskich dawnych redakcjach, które określały reguły życia w danym monasterze. (Ławreszuk, 2009, s. 167-169; Lenczewski, 1981, s. 185)

5 W XV w. ruska Cerkiew rozpoczyna zmianę z obowiązującej dotychczas reguły Studyjskiej na regułę Jerozolimską. Propagatorem owej zmiany był metr. Focjusz (metropolita kijowski w latach 14081431), zaś Typikon Jerozolimski przyjęty został na Rusi za czasów metr. Cypriana (zm. w 1408 r.). Jednak owej modyfikacji nie udało się dokonać w pełni. Fakt ten spowodował, iż przez jakiś czas obrzędy oraz śpiewy obecne w katedrach metropolitalnych różniły się znacząco od tych wykonywanych w świątyniach parafialnych. Modyfikacja reguł liturgicznych niosła za sobą poważne zmiany, ponieważ Typikon Studyjski i Jerozolimski różniły się od siebie: rodzajami sprawowanych nabożeństw, a co za tym idzie odrębną ich hymnografią; przewagą śpiewu nad recytacją podczas nabożeństw itd. (Ławreszuk, 2009, s. 184-185; Sawicki, 2013, s. 64; Skaballanovich, 2004, s. 492-494)
}

11, 22, 23 i 24-tym ${ }^{6}$. Sobór stwierdza, iż Boską Liturgię sprawować należy we wszystkich szatach liturgicznych,

„z bojaźnią i drżeniem, nie myśląc o niczym, co ziemskie" (Stoglav", 1862, s. 88).

Liturgia musi być sprawowana zgodnie z rytami i przekazami świętych: Bazylego Wielkiego ${ }^{7}$, Jana Chryzostoma $^{8}$ oraz Grzegorza Dialoga9. Mówiąc o I części Boskiej Liturgii - proskomidii, sobór wystąpił przeciwko złym praktykom niektórych kapłanów, polegających na niewyjmowaniu cząsteczek za żywych czy też zmarłych z przynoszonych na proskomidie - prosfor ${ }^{10}$. Prosfornice nie mogą nic mówić nad prosforami, tylko modlitwę Jezusową, z błogosławieństwa biskupa lub kapłana mogą jeszcze odbijać na przyniesionej prosforze pieczęć ze znakiem krzyża. Gtawa reguluje ponadto cechy wymagane od prosfornic, ich wiek oraz inne obowiązki (Stoglav", 1862, s. $87-88)$.

W odniesieniu do pytania 24 postanowiono, iż ponomari, diaki, jak również wszystkie osoby wchodzące w skład osób posługujących w ołtarzu mogą wstępować w związek małżeński tylko raz.

\section{Gtawa 9}

Gtawa 9 (Stoglav", 1862, s. 88-96) rozpoczyna się od schematu „modlitw wejścia”, który kapłan i diakon powinni wypełniać podczas wejścia do świątyni. Ryt ten wygląda następująco:

6 Treść pytania 11.: „O złych praktykach prosfornic oraz o sprawowaniu proskomidii przez kapłanów niezgodnie z ustalonym rytem"; Treść pytania 22.: „O skrajnych zaniedbaniach kapłanów w świątyniach i o zgorszeniu płynącym z tego powodu dla wiernych"; Treść pytania 23.: „O celebrowaniu przez kapłanów nabożeństw i posług cerkiewnych bez określonych w regułach szat liturgicznych"; Treść pytania 24.: „O ponomarach i diakach, posługujących w ołtarzu, którzy drugi lub trzeci raz przyjęli sakrament małżeństwa”. (Bočkarev, 1906, s. 43)

7 Liturgia św. Bazylego Wielkiego - sprawowana jest 10 razy w roku: 5 niedziel Wielkiego Postu, Wielki Czwartek, Wielką Sobotę, w wigilię świąt Narodzenia Chrystusa oraz Chrztu Pańskiego, w dzień pamięci św. Bazylego Wielkiego - 1/13 stycznia. Jej autorem jest św. Bazyli Wielki, arcybiskup Cezarei Kapadockiej (329 - 379). (Lenczewski, 1981, s. 225228).

8 Liturgia św. Jana Chryzostoma - jest to liturgia sprawowana najczęściej w Cerkwi prawosławnej. Czas jej powstania i autorstwo są trudne do określenia. Kształtuje się ostatecznie w XI w. Pewne jest, iż św. Jan nie jest jej autorem. Zob. (Liturgie Kościoła prawosławnego, 2003, s. 63-65).

9 Mowa jest tutaj o Liturgii Uprzednio Poświęconych Darów - odprawiana jest w środy i piątki Wielkiego Postu, w czwartek piątego tygodnia Wielkiego Postu oraz w Wielki Poniedziałek, Wielki Wtorek oraz Wielką Środę. W okresie Wielkiego Postu, od poniedziałku do piątku, Boska Liturgia nie jest odprawiana. Sprawowana jest ona po to, aby wierni w te dni mogli przystąpić do Eucharystii. Dary poświęcane są podczas Boskiej Liturgii sprawowanej w poprzednią niedzielę. Ryt Liturgii jest połączony z wieczernią. (Borowik, 2001, s. 131-132).

10 Prosfora - chleb liturgiczny upieczony z białej mąki z dodatkiem zakwasu, używany przy sprawowaniu sakramentu Eucharystii. (Fediukina, 2014, s. 202). 


\section{\begin{tabular}{|c|c|c|}
\hline Tekst Stoglawa \\
\hline „Станут убо вкупе пред дверьми церковными западными \\
в паперти и вход творят сотворь три поклоны.
\end{tabular}}

Дьякон: Благослови, владыко.

Иерей глаголет: Благословен бог наш.

Таже: Царю небесный, Трисвятое, по Отче наш, иерей возглас: Я ко твое есть царство.

Посем: Господи, помилуй. х 12. Слава, и ныне, Приидете поклонимся трижды.

Таже глаголют тропари сия:

Радуйся двери божия; радуйся, пречистая дево святая, радуйся, владычице и заступнице миру, радуйся, стено и прибежище и покрове граду нашему.

Под твою милость прибегаем. Богородице дево, молитв наших не презри в скорбех, но от бед избави нас, едина чистая и благословенная!

Господи, отъими от мене беззакония моя и прегрешения моя, да достойно вниду в достояние святаго храма твоего, непроходимая двери тайно знаменана!

Благословенная Богородице, дево, приими молитвы наша и донеси я Сыну своему и богу нашему, да спасет тебе ради душа наша.

И посем глаголи тропарь настоящаго дни святаго или святителя или велика мученика, или преподобного отца или апостола и евангелиста.

Святый христов, (имярек), пострадавый за Христа, имея дерзновение к нему молися о мне, грешном и недостойном рабе своем, священноиноке или священноиереи (имярек).

И целуют у дверей на столпцех по странам Спасов образ и пречистой или кресты.

И посем входят в церковь священник с дьяконом и сотворяют вкупе к востоком поклоны три, глаголюще тропарь:

Пречистому образу поклоняемся,

Слава и ныне, Богородичен,

Бога из тебе воплощшася разумехом.

Таже тропарь дню, и храму, и святому, и за упокой, и кондак.

Сия глаголюще, знаменуются и целуют святыя образы. Также к правой стороне поклон един и к левой такоже. И отходят малыми дверми к жертвеннику, глаголюще в себе тай молитву:

Господи, низпосли руку твою с высоты жилища твоего" (Stoglav", 1862, s. 88-90).

\section{Tłumaczenie na język polski}

Stanąwszy razem przed zachodnimi drzwiami cerkwi, w przedsionku i czynią obrzęd wejścia, kłaniając się trzykrotnie.

Diakon: Pobłogosław, władyko.

Kapłan: Błogosławiony Bóg nasz.

Następnie: Królu Niebieski, Trójświęte, po Ojcze nasz, kapłan wygłasza aklamację: Albowiem Twoje jest królestwo.

Po tym: Panie zmiłuj się. x 12. Chwała, i teraz, Przyjdźcie pokłońmy się... trzykrotnie.

Następnie mówią tropariony:

Raduj się, która jesteś wrotami do Boga, Raduj się, przeczysta święta Dziewico, Raduj się, władczyni i orędowniczko świata, Raduj się twierdzo i schronienie i opieko naszego miasta.

Pod Twoje miłosierdzie przybiegamy, Bogurodzico dziewico, naszymi modłami nie pogardzaj w utrapieniach, lecz wybaw nas od nieszczęść, jedyna Czysta, jedyna Błogosławiona!

Panie, odrzuć ode mnie nieprawości moje i grzechy moje, abym z godnością mógł wejść do świętego przybytku Twojego, w tajemniczy sposób wrota, których nie da się przejść pieczętując.

Błogosławiona Bogurodzico, Dziewico, przyjmij modlitwy nasze i zanieś je przed oblicze Twojego Syna i Boga naszego, aby dzięki Tobie zbawił dusze nasze.

Następnie wygłasza tropariony czczonego tego dnia świętego lub świętego biskupa, lub wielkiego męczennika, lub świętego mnicha, lub apostoła czy też ewangelisty.

Święty Chrystusowy, (imię), który doznałeś cierpień za Chrystusa, posiadający odwagę, aby modlić się do Jego w moim imieniu, grzesznego i niegodnego sługi, kapłana (imię)

I całują leżące na pulpitach, przy drzwiach, po odpowiednich stronach ikony: Zbawiciela i Bogurodzicy lub krzyże.

Następnie wchodzą do cerkwi, kapłan z diakonem i razem

kłaniają się trzykrotnie na Wschód, mówiąc tropariony:

Przeczystej Twojej Ikonie oddajemy pokłon,

Chwała i teraz, Teotokion,

Boga, który dzięki Tobie stał się człowiekiem, poznaliśmy.

Następnie troparion przypadającego dnia, świątyni, ku czci (K.W.) świętego, za zmarłych oraz kondakion.

Podczas ich wygłaszania czynią znak krzyża i całują święte ikony. Następnie kłaniają się raz ku prawej stronie, raz ku lewej stronie. I odchodzą diakońskimi wrotami do żertwiennika ${ }^{1}$, mówiąc po cichu modlitwę:

Panie, podnieś rękę Twoją z wysokości świętego Twego przybytku (thumaczenie autora)

Żertwiennik (Stół ofiarny) - umieszcza się zwykle z lewej strony części ołtarzowej. Przypomina on żłóbek betlejemski, jak również Golgotę. Na stole ofiarnym przygotowuje się dary dla św. Eucharystii - chleb i wino. (Bondaruk, 1987, s. 29).

W dalszej części 9 gławy mowa jest o tym, że podczas sprawowania Proskomidii czytane są godziny kanoniczne (cs. Czasy). Pytanie 11, dane przez cara podczas rozpoczęcia soboru, traktuje o złych praktykach, które kapłani wprowadzają podczas sprawowania proskomidii. W związku z tym Stogław nakazuje, że powinna odbywać się według. następującego rytu: kapłan -1) wycina agniec $^{11} \mathrm{z}$ pierwszej prosfory; 2) wlewa do czaszy wodę i wino; 3) wycina cząsteczkę z drugiej prosfory ku czci Przenajświętszej Bogurodzicy i kładzie po prawej stronie agnca; 4) z trzeciej

\footnotetext{
11 Agniec - wykrojona z prosfory ofiarnej w czasie proskomidii środkowa część symbolizująca Chrystusa, która stanowi przedmiot ofiary eucharystycznej. (Fediukina, 2014, s. 202).
}

prosfory wyjmuje cząsteczkę ku czci św. Jana Chrzciciela i kładzie po lewej stronie agnca; 5) z pozostałych prosfor wyjmuje cząsteczki w intencji wszystkich biskupów prawosławnych, za cara, za książęta oraz za wszystkich chrześcijan żyjących oraz zmarłych (te cząsteczki kładzie poniżej agnca); 6) pokrywa Święte Dary pokrowcami oraz wozduchem ${ }^{12}$. Niektórzy duchowni nie pokrywali darów wozduchem, co sobór potępił (Stoglav", 1862, s. 90-93).

12 Pokrowcy $i$ wozduch- są to trzy płócienne narzuty: na kielich i patenę (małe pokrowce) mają kształt krzyża, zaś trzeci pokrowiec (wozduch), zwany dużym - formę prostokąta. Pokrowce małe symbolizują aniołów otaczających niebieski tron Boga, zaś duży - szaty, w które zawinięty był Chrystus po narodzeniu oraz po złożeniu do grobu. (Borowik, 2001, s. 30). 
Sobór Stu Rozdziałów nie wprowadza żadnych zmian, czy ujednoliceń, jeżeli chodzi o ryt Liturgii Katechumenów oraz Wiernych. Wypowiada się tylko w sprawie błędów w pojedynczych słowach, czy też sformułowaniach, modlitw oraz hymnów liturgicznych. Owe zmiany zapisane zostały w drugiej części 9 gławy. Poniżej przedstawione są teksty liturgiczne, które były w użyciu przed soborem, poprawki, jakie wniósł sobór, oraz tekst używany współcześnie.

\begin{tabular}{|c|c|c|}
\hline $\begin{array}{c}\text { Tekst używany przed Soborem Stu } \\
\text { Rozdziałów }\end{array}$ & $\begin{array}{c}\text { Tekst poprawiony przez Sobór Stu } \\
\text { Rozdzialów }\end{array}$ & $\begin{array}{c}\text { Teks będący w użyciu we wspólczesnej } \\
\text { praktyce liturgicznej. }\end{array}$ \\
\hline \multicolumn{3}{|c|}{ 1) Jedna z próśb Wielkiej Ektenii ${ }^{1}$} \\
\hline $\begin{array}{c}\text { „ архиепископе нашем, (имярек), } \\
\text { и о честном его прозвитерстве” } \\
\text { (Bočkarev, 1906, s. 182). }\end{array}$ & $\begin{array}{c}\text { „о архиепископе нашем, (имярек), } \\
\text { честного его прозвитерства и еже о } \\
\text { Христе дьяконства и всего причта” } \\
\text { (Stoglav", 1862, s. 94). }\end{array}$ & 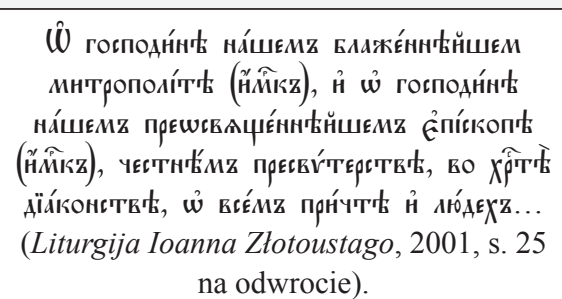 \\
\hline $\begin{array}{l}\text { (o arcybiskupie naszym (imię), } \\
\text { i o czcigodnych jego prezbitrach) }\end{array}$ & $\begin{array}{l}\text { (o arcybiskupie naszym (imię), } \\
\text { czcigodnych jego prezbitrach } \\
\text { i w Chrystusie diakonach } \\
\text { i całym stanie duchownym) }\end{array}$ & $\begin{array}{c}\text { (Za wielce błogosławionego metropolitę } \\
\text { naszego (imię), i najprzewielebniejszego } \\
\text { biskupa naszego (imię), za czcigodnych } \\
\text { prezbitrów, w Chrystusie } \\
\text { diakonów, za cały stan duchowny i lud...) } \\
\text { (Boska Liturgia świętego ojca naszego Jana } \\
\text { Chryzostoma, 2001, s. 36) }\end{array}$ \\
\hline \multicolumn{3}{|c|}{ 2) Ósmy artykuł Symbolu Wiary } \\
\hline $\begin{array}{c}\text { „и в Духа святаго Господа } \\
\text { истинного...” (Stoglav", 1862, s. 94). } \\
\text { (I w Ducha Świętego, Pana } \\
\text { prawdziwego...) }\end{array}$ & $\begin{array}{c}\text { „и в Духа святаго истинного } \\
\text { и животворящаго...” (Stoglav", 1862, } \\
\text { s. 94) } \\
\text { (I w Ducha Świętego prawdziwego } \\
\text { i ożywiciela.) }\end{array}$ & 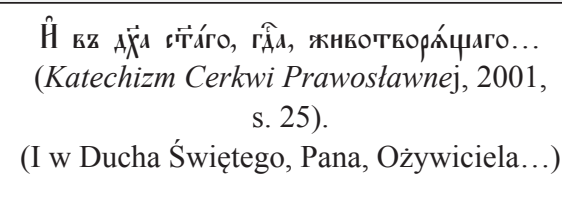 \\
\hline \multicolumn{3}{|c|}{ 3) Jedna z próśb Ektenii Żarliwej² wygłaszanej po przyjęciu Św. Eucharystii } \\
\hline $\begin{array}{c}\text { „День весь совершен, свят, } \\
\text { мирен, безгрешен, испросивше } \\
\text { у Христа. сами себе и друг другу...” } \\
\text { (Stoglav", 1862, s. 94-95). }\end{array}$ & $\begin{array}{c}\text { „День весь совершен, свят, мирен, } \\
\text { безгрешен, испросивше себе, (или } \\
\text { сами себе, то едина сила) и друг } \\
\text { другу и весь живот наш Христу богу } \\
\text { предадим” (Stoglav", 1862, s. 94-95). }\end{array}$ & 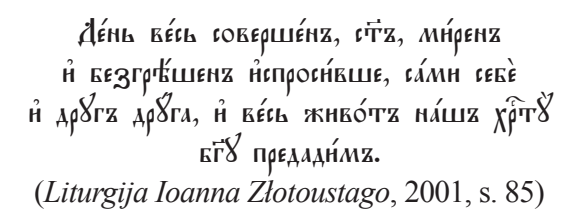 \\
\hline $\begin{array}{l}\text { (O cały ten dzień doskonały, święty, } \\
\text { spokojny i bezgrzeszny, prosząc } \\
\text { Chrystusa, sami siebie, wszyscy siebie } \\
\text { nawzajem...) }\end{array}$ & $\begin{array}{l}\text { (O cały ten dzień doskonały, święty, } \\
\text { spokojny, bezgrzeszny, prosząc siebie } \\
\text { (lub sami siebie, to ta sama siła), } \\
\text { wszyscy siebie nawzajem, i całe życie } \\
\text { nasze Chrystusowi Bogu oddajmy.) }\end{array}$ & $\begin{array}{l}\text { (O cały ten dzień doskonały, święty, } \\
\text { spokojny i bezgrzeszny, prosząc } \\
\text { sami siebie, wszyscy siebie nawzajem, } \\
\text { i całe życie nasze Chrystusowi Bogu } \\
\text { oddajmy). } \\
\text { (Boska Liturgia świętego ojca naszego } \\
\text { Jana Chryzostoma, 2001, s. 106) }\end{array}$ \\
\hline \multicolumn{3}{|c|}{ 4) Ostania prośba Ektenii Błagalnej wygłaszanej podczas Boskiej Liturgii przed Modlitwą Pańską (Otcze Nasz) } \\
\hline $\begin{array}{c}\text { „Единение веры и причастие святого } \\
\text { Духа испросивше у Христа сами } \\
\text { себе и друг другу” } \\
\text { (Stoglav", 1862, s. 95). } \\
\text { (Jedność w wierze, i udział we } \\
\text { wspólnocie Świętego Ducha } \\
\text { uprosiwszy Chrystusa, sami siebie, } \\
\text { wszyscy siebie nawzajem.) }\end{array}$ & $\begin{array}{c}\text { „Единение веры и причастие святого } \\
\text { Духа испросивше себе и друг другу } \\
\text { и весь живот наш Христу богу } \\
\text { предадим” (Stoglav", 1862, s. 95). } \\
\text { (Jedność w wierze, i udział we } \\
\text { wspólnocie Świętego Ducha uprosiwszy, } \\
\text { siebie, wszyscy siebie nawzajem, i całe } \\
\text { życie nasze Chrystusowi Bogu oddajmy.) }\end{array}$ & 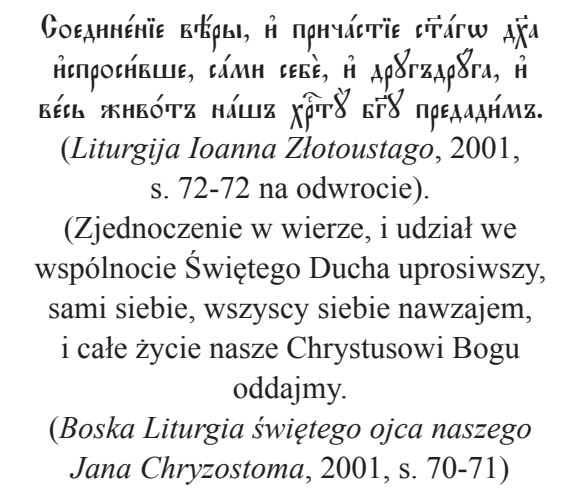 \\
\hline
\end{tabular}


5) Fragment wspomnienia biskupów podczas Anafory ${ }^{3}$

\begin{tabular}{|c|c|c|}
\hline $\begin{array}{c}\text { „Впервых помяни Господи } \\
\text { архиепископа нашего (имярек), его } \\
\text { же даровал есu (или дал)...” } \\
\text { (Stoglav", 1862, s. 96). }\end{array}$ & $\begin{array}{c}\text { „Впервых помяни Господи } \\
\text { архиепископа нашего (имярек), его } \\
\text { же даждь (или даруй), святым твоим } \\
\text { церквам” (Stoglav", 1862, s. 96). }\end{array}$ & 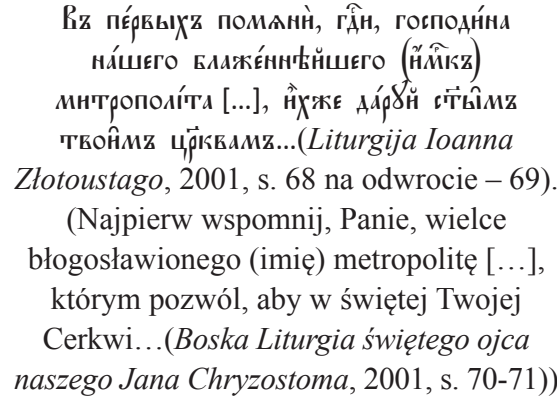 \\
\hline \multicolumn{3}{|c|}{ 6) Fragment psalmu 91 czytanego podczas Jutrzni } \\
\hline $\begin{array}{c}\text { „Возвещати заутра милость твою } \\
\text { и истину твою на всяк день” } \\
\text { (Stoglav", 1862, s. 95). } \\
\text { Lub też: } \\
\text { Возвещати заутра милость твою } \\
\text { и истину твою на всяко время } \\
\text { (Stoglav", 1862, s. 95). } \\
\text { (Ogłaszać od rana miłosierdzie Twoje } \\
\text { i prawdę Twoją każdego dnia.) } \\
\text { Lub też: } \\
\text { (Ogłaszać od rana miłosierdzie Twoje } \\
\text { i prawdę Twoją w każdym czasie.) }\end{array}$ & $\begin{array}{c}\text { Благо есть исповедатися Господеви и } \\
\text { пети имени твоему вышний возвещати } \\
\text { заутра милость твою и истину твою на } \\
\text { всяку нощъ (Stoglav", 1862, s. 95). }\end{array}$ & 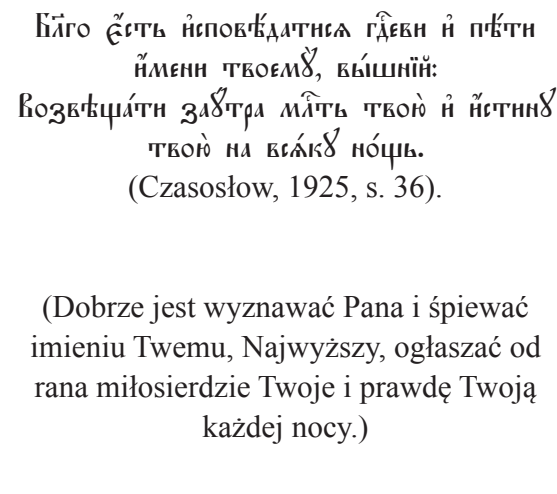 \\
\hline \multicolumn{3}{|c|}{ 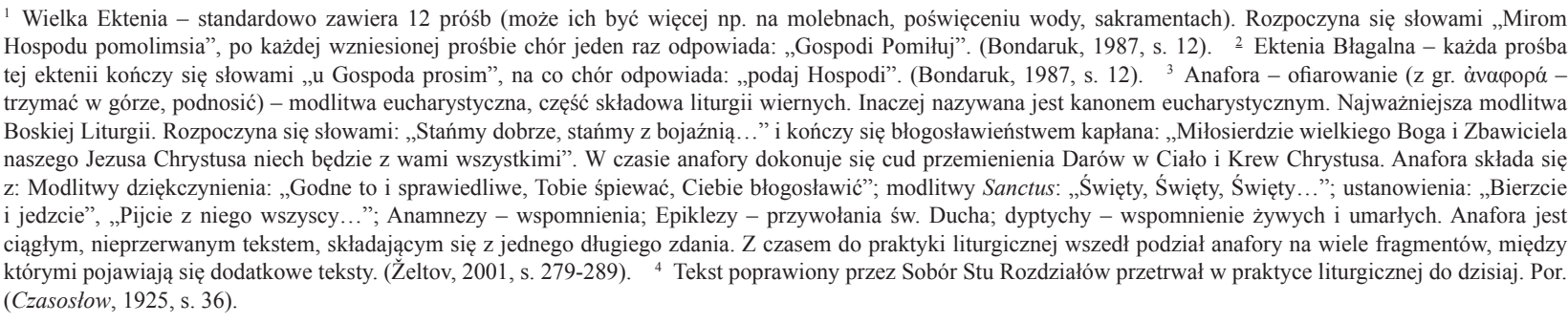 } \\
\hline
\end{tabular}

Jak możemy wywnioskować z przytoczonych przykładów, zmiany wprowadzone przez Sobór Stu Rozdziałów, zapisane w 9. gławie jego postanowień i tak nie były prawidłowym tłumaczeniem tekstów liturgicznych (oprócz treści psalmu 91, recytowanego na Jutrzni).

\section{Gtawa 10}

Gława 10 (Stoglav", 1862, s. 96) jest odpowiedzią na 23 pytanie cara z I grupy. W owym pytaniu Iwan IV wskazuje na to, że duchowni sprawują nabożeństwa bez odpowiednich szat liturgicznych. Gława mówi o obowiązkowym nakładaniu przez duchownych jepitrachila ${ }^{13}$ i rizy ${ }^{14}$.

Dalsza część wspomnianego pytania wskazywała na to, że kapłani często w czasie służby bez potrzeby korzystają z Carskich Wrót. W 10 gławie wskazane są te momenty,

\footnotetext{
13 Jepitrachil - szata liturgiczna nakładana przez kapłana i biskupa na szyję, symbolizuje łaskę Bożą która mu została dana w czasie święceń, bez niego nie można odprawiać nabożeństw. (Bondaruk, 1987, s. 52-53).

14 Fieloń (Riza) - szeroka, długa szata, bez rękawów, symbolizująca odzież, w którą ubrano Jezusa Chrystusa na dworze u Piłata. (Bondaruk, 1987, s. 52-53).
}

kiedy wrota mogą być otwierane podczas nabożeństw wieczerni oraz jutrzni. Wyjątkiem od ogólnie obowiązującego prawa, było nabożeństwo sprawowane przez biskupa. Zabroniono również duchownym przechodzenia przez Carskie Wrota bez szat liturgicznych (minimum jepitrachila i rizy) oraz w nieodpowiednim czasie (Gorskij, A. (red.), 1985, s. 434; Bočkarev, 1906, s. 184).

\section{Gtawa 11}

Gława 11 (Stoglav", 1862, s. 97-98) stanowi kontynuacje odpowiedzi na pytanie 23 i dotyczy odsłaniania i zasłaniania zawiesy ${ }^{15}$. Przede wszystkim sobór reguluje to, że przy każdych Carskich Wrotach, musi być zawiesa.

Rozdział przedstawia następujące reguły:

1) „...po zakończeniu sprawowania proskomidii przed otpustem godzin kanonicznych zawiesa jest odsłaniana i po otpustie godzin kanonicznych Carskie Wrota są zamykane. Zawiesa zaś jest odsłonięta aż do momentu przeniesienia Świętych Darów z żertwiennika na pre-

\footnotetext{
15 Zawiesa-kotara wisząca za Carskimi wrotami. Przyp. aut. K.W. (ks.).
} 
stoł, wtedy zamykane są Carskie Wrota i zasłaniana jest zawiesa i nie są otwierane do momentu udzielania Eucharystii. Po rozesłaniu kończącym Boską Liturgię Carskie Wrota są zamykane a zawiesa zasłaniana. Tak jest, kiedy Boską Liturgię sprawuje jeden kapłan. W sytuacji, kiedy służy z nim diakon, zawiesa otwierana jest na ispolniaja molitwy, po Izdradno, a zasłaniana jest po Swjataja swjatym, zasłonięta jest do udzielania Eucharystii, jak powiedziano wyżej” (Stoglav", 1862, s. 97-98).

2) Podczas wieczerni, jutrzni, molebnów, zawiesa odsłonięta musi być przez całe nabożeństwo (Stoglav", 1862, s. 97-98).

3) Kiedy godziny kanoniczne sprawowane są bez Boskiej Liturgii, zawiesa odsłaniana powinna być od czytania lekcji apostolskiej i zasłaniana po otpustie (Stoglav", 1862, s. 97-98).

\section{Gtawa 12}

Gtawa 12 (Stoglav", 1862, s. 99.100) jest pouczeniem o tym, co można wnosić do ołtarza. Sobór zabrania wnoszenia do ołtarza rzeczy, które nie są potrzebne do sprawowania nabożeństw (wspominane są np.: piwo, miód, chleb, jedzenie, ludzkie dobra). Określono, że do najważniejszej części świątyni wnieść można: świece, tadan (kadzidło), wino liturgiczne, gorącą wodę i naczynia do ewentualnego przygotowania wrzątku oraz księgi liturgiczne.

Analizowany rozdział określa również, że na prestoł oraz żertwiennik można kłaść następujące przedmioty: Ewangelia, Krzyże, utensylia liturgiczne, pokrowcy i wozduch i pozostałe rzeczy poświęcone.

Opisywana gława przypomina również, aby duchowni nie pozwalali wchodzić do ołtarza ludziom postronnym oraz tym, którzy po raz drugi (i więcej) wzięli ślub.

\section{Gtawy 14-16}

W glawach 14-16 (Stoglav", 1862, s. 101-107) zawarte są przepisy dotyczące zakładania przez kapłanów szat liturgicznych podczas nabożeństw. 14 rozdział rozpoczyna się od wskazania, aby duchowni

„dzieci chrzcili, udzielali sakramentu małżeństwa, oświęcali wodę w wigilię święta Objawienia Pańskiego - w pełnym obłaczeniju. Wieczernie, panichidy, połunosznice, jutrznie i molebny sprawowali w jepitrachili i rizie" (Stoglav", 1862, s. 101-102).

Jak widać z przytoczonego fragmentu Stogława, 14 rozdział mówi o obowiązku zakładania przez kapłanów szat liturgicznych podczas sprawowania nabożeństw, zaś w 15 rozdziale zsyłając się na Świętych Ojców, sobór wyjaśnia fundamenty tego obowiązku i na zasadzie alegorii opisuje znaczenia szat liturgicznych (Stoglav", 1862, s. 102-106).

Gławę 16, można podzielić na 4 części, jednak aspekt teologii praktycznej zawarty jest w pierwszych dwóch oraz ostatniej. Pierwsza część owego rozdziału jest kontynuacją postanowień dotyczących ubioru liturgicznego kapłanów. $\mathrm{Na}$ zakończenie regulacji norm dotyczących szat, wskazane są sankcje, jakie mogą czekać tych, którzy będą je naruszać. Duchowny, który nie będzie przestrzegał zasad zakładania określonych szat liturgicznych, będzie zawieszony w czynnościach kapłańskich, bez różnicy, której szaty nie założy. Jednocześnie mowa jest o tym, że pomimo kary nałożonej podczas życia ziemskiego, duchownego po śmierci czeka kara o wiele cięższa (Gorskij, A. (red.), 1985, s. 435).

Druga i czwarta część 16 gławy zawiera odpowiedź na 22 i 33 pytania carskie ${ }^{16}$. W tym rozdziale zauważamy ważne postanowienia dotyczące carskich pytań, ale również zmieniające nieco ich sens. W pytaniach szczególny nacisk kładziony był na to, że nabożeństwa w cerkwiach są skracane oraz że teksty, które powinny być czytane, są śpiewane itd. Uczestnicy soboru zwracają uwagę nie tylko na obowiązek służby zgodnie z cerkiewną regułą (ustawem), ale również na to, żeby sprawować je: cicho, spokojnie, z uwagą. Sobór surowo zakazuje praktykowania „wielogłosowości" ${ }^{17}$ :

„aby jednocześnie dwóch psalmów nie śpiewali, podobnie w przypadku kanonów aby jednocześnie nie śpiewali hirmosów i czytali tropariony" (Stoglav", 1862, s. 105).

Początkowo zakaz ten objął głównie świątynie Moskwy. Próba wykluczenia mnogogłasija była nieudana do czasów reform przeprowadzonych przez patr. Nikona. Owo postanowienie nakazuje także, aby kanony były czytane, a nie śpiewane. $\mathrm{Z}$ tego możemy wywnioskować, że do czasu soboru tropariony kanonów były śpiewane (tak jak w Grecji) (Gardner, 1978, s. 450). W temacie śpiewu cerkiewnego Sobór Stu Rozdziałów postanowił również, iż bezdyskusyjnie podczas nabożeństwa Całonocnego Czuwania - Wielka Doksologia - musi być śpiewana (Gusiejnowa, 2005, s. 457).

\section{Gtawa 17}

Gtawa 17 (Stoglav", 1862, s. 108-110) Stogława dotyczy sakramentu chrztu. Nie jest ona bezpośrednią odpowiedzią na żadne z carskich pytań. Pośrednio zaś odpowiada na pytania: 1. (dotyczące ogólnie sprawowania obrzędów cerkiewnych zgodnie z ustawem) oraz 23. (mówiącego o tym, że kapłani podczas sprawowania sakramentu chrztu nie zakładają pełnych szat liturgicznych). Pomimo tego, że temat chrztu nie był poruszany w carskich pytaniach, to

\footnotetext{
Pytania 22 i 33 dotyczyły porządku nabożeństw. (Stoglav", 1862, s. $65-66,73)$.

17 Praktyka wielogłosowości pojawiła się na Rusi w wyniku zastosowania w XV w. w cerkwiach parafialnych monasterskiej reguły liturgicznej. Ten sposób praktykowania śpiewu i czytania jednokrotnie pojawił się w praktyce cerkiewnej, gdyż teksty liturgiczne było bardzo liczne i aby nie rozciągać w czasie i tak długiego nabożeństwa, w tym samym czasie śpiewano i czytano. Śpiew przy tym był jednogłosowy, grecki. Taka praktyka wprowadzała wielki nieporządek i nieczytelność treści nabożeństw. (Anchimiuk, 2003, s. 18; Korobin, Michajłowa, 1999, s. 20; Wołosiuk, 2003, s. 40, Metallov, 1990., s. 72).
} 
był on przez długi czas w sferze zainteresowań hierarchów. W latach 1392-1395 metropolita Cyprian dwukrotnie w swoich listach zwracał się do duchowieństwa w sprawie sprawowania sakramentu chrztu. W jednym z tych listów skierowanym do duchowieństwa z Pskowa, krytykuje chrzczenie przez polewanie, które weszło w praktykę tamtejszych Cerkwi. Metropolita Focjusz również krytykuje w 1430 r. ową praktykę. Widzimy z tych listów, iż w Cerkwi ruskiej problem ten był żywy. Inną kwestią dotyczącą sakramentu chrztu, była obecność podczas chrztu tylko ojca chrzestnego lub matki chrzestnej. W tej sprawie metropolita Cyprian wypowiada się w drugim liście w 1395 r., zaś przed rozpoczęciem Soboru Stu Rozdziałów, temat ten porusza bp Kasjan (Gorskij, A. (red.), 1985, s. 436).

O sakramencie chrztu Stogław przedstawia następujące reguły:

1) „Dzieci należy chrzcić w cerkwiach, zgodnie z ustawem i przekazem św. Apostołów i św. Ojców, nie przez polanie a przez trzykrotne zanurzenie chrzczonego w wodzie"(Stoglav", 1862, s. 108).

Owo postanowienie wynikło z faktu, iż łaciński zwyczaj chrzczenia przez polanie głowy wodą, przenikał do praktyki Cerkwi prawosławnej szczególnie na terenach graniczących z państwami katolickimi (np. Nowgorod oraz Psków). Zaś w czasach, kiedy odbył się Sobór Stu Rozdziałów, praktyka ta nie była aż nadto rozpowszechniona na terenie ówczesnej Rusi. Wprowadzenie tego postanowienia miało na celu wzmocnienia cerkiewnego autorytetu wskazanym wcześniej tekstom metropolitów: Cypriana oraz Focjusza.

2) Zanurzenie musi być trzykrotne.

Stogław w odniesieniu do 49. kanonu Postanowień Apostolskich ${ }^{18}$ stwierdza, iż:

„... zgodnie z 49 kanonem Apostolskim, pozbawiony godności będzie kapłan, który chrzci wypowiadając następujące słowa: Chrzczony jest sługa Boży (imię), w imię Ojca i Syna i Świętego Ducha, teraz i zawsze i na wieki wieków, Amen; i zanurza chrzczonego w wodzie, następnie powtarza te same słowa i ponownie zanurza, i trzeci raz wypowiada te słowa i zanurza w wodzie. Mówiąc tak, chrzci w imię trzech wiecznych, trzech synów i trzech pocieszycieli, a więc chrzci w imię dziewięciu osób, a nie trzech. Tak samo pozbawiony godności zostaje, zgodnie z 50. ${ }^{19}$ kanonem Apostolskim, ów kapłan, który wypowiada te słowa, lecz zanurza chrzczone dziecko tylko raz, nie wychwalając przez to zmartwychwstania" (Stoglav", 1862, s. 108-109).

\footnotetext{
18 Treść 49. kanonu Postanowień Apostolskich brzmi następująco: „Jeżeli którykolwiek biskup lub prezbiter chrzci niezgodnie z ustanowieniem Pana: w imię Ojca i Syna i Świętego Ducha, lecz w imię trzech wiecznych, albo w imię trzech synów, albo trzech pocieszycieli, niech będzie pozbawiony godności”. Na podstanie: (Znosko, 2000, s. 23).

19 Treść 50. kanonu Postanowień Apostolskich brzmi następująco: Jeżeli którykolwiek biskup lub prezbiter dokona podczas sakramentu chrztu nie trzech, lecz jednego zanurzenia, symbolizującego śmierć Pana, niech będzie pozbawiony godności. Albowiem nie powiedział Pan: „W Moją śmierć chrzcijcie” - lecz: „idąc nauczajcie wszystkie narody, chrzcząc je w imię Ojca, i Syna i Świętego Ducha” (Mt. 28:19). (Znosko, 2000, s. 23).
}

3) Określenie prawidłowego sposobu chrztu.

Sobór Stu Rozdziałów postanawia, iż kapłan bierze na ręce chrzczone dziecko i wypowiada słowa:

„Chrzczony jest sługa Boży (imię), w imię Ojca Amen, zanurza i wyjmuje z wody; i Syna Amen zanurza i wyjmuje z wody; Świętego Ducha, teraz i zawsze na wieki wieków Amen, zanurza i wyjmuje z wody" (Stoglav", 1862, s. 108).

Od razu po tym obrzędzie kapłan oddaje chrzczonego dla wospryjemnika ${ }^{20}$, następnie namaszczany jest ,wielkim mirem"21 oraz ubierany (przyoblekany) jest w nową szatę. W tym czasie śpiewany jest psalm 31. (Stoglav", 1862, s. 109). Ryt, który wprowadził Stogław, różni się nieco od praktykowanego współcześnie. Różnica polega na tym, że we współczesnych Trebnikach ${ }^{22}$, nałożenie nowej szaty i śpiewanie psalmu 31-ego sprawowane jest przed bierzmowaniem, a nie po (Trebnik, 2004, s. 51-55).

17 gława kończy się postanowieniem, mówiącym o tym, że chrzestny powinien być tylko jeden ${ }^{23}$.

\section{Gtawy 18-24}

Gtawy od 18 do 24 (Stoglav", 1862, s. 110-120) traktują o sakramencie małżeństwa. Szczególną uwagę poświęca się w nich tematom, które dotyczą szczegółów sprawowania sakramentu oraz poszczególnych przypadków zawarcia małżeństwa. Niemniej jednak rozdziały te zawierają normy regulujące relacje małżeńsko-rodzinne (Gorskij, A. (red.) 1985, s. 437).

Stogław zawiera następujące postanowienia na temat małżeństwa:

1) Obrzęd zaręczyn oraz obrzęd koronowania ${ }^{24}$ zgodnie z ustawem cerkiewnym, kapłani powinni sprawować w kompletnych szatach liturgicznych (Gtawa XVIII, Stoglav", 1862, s. 110).

2) Sakrament powinien być sprawowany w dzień, bezpośrednio po Boskiej Liturgii. Nie może być sprawowany w nocy (Gtawa XVIII, Stoglav", 1862, s. 110).

3) Oblubieniec musi mieć ukończone 15 lat, oblubienica zaś $12^{25}$ (Gtawa XVIII, Stoglav", 1862, s. 110).

\footnotetext{
20 Wospryjemnik - rodzic chrzestny, w zależności od płci dziecka (jeżeli chrzczony jest chłopiec - wtedy wospryjemnikom jest mężczyzna, jeżeli dziewczynka - wtedy analogicznie kobieta). Przyp. aut. K.W. (ks.).

${ }^{21}$ Mowa jest tutaj o Sakramencie Bierzmowania. Przyp. aut. K.W. (ks.). 22 Trebnik - księga zawierająca modlitwy i obrzędy, stosowane dla potrzeb jednego lub kilku wiernych w zależności od okoliczności ich życia. W trebniku zawarte są również ryty sprawowania sakramentów, poza eucharystią oraz kapłaństwem. (Lenczewski, 1981, s. 14)

23 W przypadku chrzczenia osoby, płci męskiej - ojciec chrzestny, w przypadku chrzczenia osoby płci żeńskiej - matka chrzestna. W obecnej praktyce PAKP są zawsze oboje rodzice chrzestni, jednak dziecko po wyjęciu z wody oddawane jest dla wospryjemnika. Przyp. aut. K.W. (ks.). 24 Obrzęd zaręczyn oraz obrzęd koronowania są to dwie części składowe sakramentu małżeństwa w Cerkwi prawosławnej. Zob. (Bondaruk, 1987, s. 134).

25 W dzisiejszej praktyce PAKP nie ma praktycznego zastosowania, ponieważ nie pokrywa się w tym zakresie z ustawą cywilną, która jest wyznacznikiem wieku zawarcia małżeństwa (Art. $10 \S 1$, Kodeks rodzinny i opiekuńczy). Ten akt prawny mówi, że: „Nie może zawrzeć małżeństwa osoba niemająca ukończonych lat osiemnastu. Jednakże z ważnych powodów sąd opiekuńczy może zezwolić na zawarcie małżeństwa kobie-
} 
4) Po zakończeniu sprawowania sakramentu, duchowny zobowiązany jest pouczyć nowożeńców, jak należy żyć zgodnie z regułami Cerkwi Prawosławnej (Gława XVIII, Stoglav", 1862, s. 110).

5) Kiedy jeden ze współmałżonków wstępuje po raz pierwszy w związek małżeński, zaś drugi po raz drugi lub trzeci, ryt sakramentu małżeństwa jest taki sam jak zwykle, z tą różnicą, że kapłan za każdym razem najpierw wypowiada imię tej osoby, która bierze ślub po raz pierwszy, a na zakończenie wznosi modlitwę za tego, który drugi raz wstępuje w związek małżeński. W sytuacji, kiedy jest to już trzeci ślub jednego ze współmałżonków, ryt jest taki jak wcześniej, tylko w modlitwie czytanej na koniec zamienia się słowa „К третьему браку” па „к третьему совокуплению”, ponieważ trzecie małżeństwo dopuszczane jest tylko ze względu na potrzebę cielesną (Gtawa XIX, Sto-

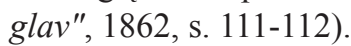

6) Kiedy oboje ze wstępujących w związek małżeński, będą to czynić po raz drugi lub trzeci, ślub sprawowany jest wg następującego rytu: kapłan ubrany jest w jepitrachil i rize, po modlitwach początkowych czyta modlitwę ${ }^{26}$, następnie czytana jest lekcja apostolska (List do Efezjan, 15, 25-33), Ektenia usilna „Pomiłuj nas Boże...", otpust (Gtawa XX, Stoglav", 1862, s. 112-113).

7) Na podstawie odpowiedzi o drugim małżeństwie błogosławionego Nikity, metropolity Iraklijskiego (XII w.) oraz 7. kanonu Soboru Lokalnego w Neocezarei $^{27}$ - Sobór Stu Rozdziałów postanawia, że kapłan po udzieleniu ślubu dla osób, które wstępują w związek małżeński po raz drugi lub trzeci, nie może uczestniczyć w przyjęciu weselnym (Gława XXII, Stoglav", 1862, s. 115).

8) Na podstawie reguły patriarchy Konstantynopolitańskiego - Nicefora (806-815 r.) (Gtawa XXI, Stoglav", 1862 , s. 115), sobór postanowil, że kto wstępuje w związek małżeński po raz drugi lub trzeci, nie jest nad nim sprawowany obrzęd koronowania, a czyta-

cie, która ukończyła lat szesnaście, a z okoliczności wynika, że zawarcie małżeństwa będzie zgodne z dobrem założonej rodziny". (Ustawa z dnia 25 lutego $1964 r$ - Kodeks rodzinny i opiekuńczy, (Tekst ujednolicony ustawy), w: „Internetowy System Aktów Prawnych”, [on-line]; (Znosko, 1975, s. 65)

26 Treść modlitwy: „Господи боже наш, иже Авраама друга назвав, и Исаака возлюбив, и Якова к жене Лии совокупив, устроивше того и второму ложу Рахилину приобщитися, сам ныне благослови рабы своя сия, имярек. Освяти иже ко второму браку, или третьему, приходящая, ради естественного искушения и еже ко юности при-лучшагося вдовства. Ты бо хотя немощи нашей Павлом сосудом избрания твоего законоположив, лучше быти телесного разжежения, еже Господи брака, немятежен тех живот соблюди, целомудренно тем пожити благоволи в повелении твоих бдящих отпряженъя соуза, яко твоя держава и твое есть царство и сила и слава Отца и Сына и святаго Духа ныне и присно и во веки веков аминь". (Stoglav", 1862, s. 112-113).

27 Treść 7. kanonu Soboru Lokalnego w Neocezarei: „Prezbiter nie śmie uczestniczyć w uczcie weselnej dwużeńca, ponieważ dwużeńcowi potrzebna jest pokuta. Cóż by to był za prezbiter, który poprzez uczestnictwo w uczcie pochwalałby takie związki małżeńskie". (Znosko, 2000, s. 134). na jest tylko modlitwa. Oprócz tego wierny odłączany jest od eucharystii na 2 lata - jeżeli bierze ślub po raz drugi (w przypadku młodego wieku odłączano na rok), zaś na 5 lat - jeżeli po raz trzeci. Sobór zabrania wstępować w związek małżeński po raz czwarty. W 23 gławie odnajdziemy również odwołanie do słów św. Grzegorza Teologa, który twierdził, iż ,pierwszy ślub - prawo naturalne, drugi - ma na celu niedopuszczenie do większego grzechu, trzeci - odstępstwo od prawa, czwarty - bezbożność, życie w czwartym małżeństwie porównywane jest do życia świni” (Gtawa XXIII, Stoglav", 1862, s. 116).

9) Kiedy miną lata epitemii nałożonej na małżonków, którzy po raz trzeci wstąpili w związek małżeński (5 lat), mogą wtedy przystępować do Eucharystii tylko raz w roku - podczas Wielkiego Postu. Kiedy taki człowiek będzie przejawiał szczerą skruchę, to jego ojciec duchowy może podjąć decyzję o wcześniejszym zakończeniu epitemii, jednak nie może to nastąpić wcześniej niż 3 lata od ślubu. Jeżeli duchowny dopuści takiego wiernego do Eucharystii wcześniej, zostaje pozbawiony stanu kapłańskiego. Innymi czynnikami, które mogły wpłynąć na wymiar kary cerkiewnej, mogły być: wiek czy też brak potomstwa z poprzednich małżeństw (Gława XXIV, Stoglav", 1862, s. 117-120).

W treści powyższych postanowień możemy zauważyć, iż pomimo dopuszczania przez Cerkiew drugiego i trzeciego małżeństwa, nakładane były epitemie na małżonków. Takie przypomnienie i podkreślenie przez Sobór Stu Rozdziałów praw dotyczących małżeństwa było spowodowane tym, że nie były one przestrzegane, ludzie wstępowali w związek małżeński po 6 czy też 7 razy. Jednak faktem historycznym jest to, iż sam Iwan IV po śmierci jego żony Anastazji, żenił się jeszcze sześć razy (Gorskij, A. (red.) 1985, s. 438).

\section{Gtawa 25}

Gtawa 25 (Gtawa XXV, Stoglav", 1862, s. 120-121) odpowiada na 20 pytanie z I grupy carskich pytań i mówi o tym, że kandydat na diakona musi mieć ukończone 25 lat, aby przyjąć święcenia diakońskie, zaś diakon, aby być wyświęconym na kapłana, musi ukończyć 30 lat ${ }^{28}$. Poruszony jest tutaj również problem, wyświęcania duchownych, którzy są słabo wykształceni.

\section{Gtawa 26}

Gtawa 26 (Gtawa XXVI, Stoglav", 1862, s. 121-123) kontynuuje temat rozpoczęty w poprzednim rozdziale postanowień soborowych, a mianowicie problem wyświęcania duchownych, którzy są słabo wykształceni. Jako

\footnotetext{
28 O kryterium wieku kapłana przyjmującego święcenia diakońskie lub kapłańskie w dzisiejszej praktyce Cerkwi prawosławnych na świecie pisze bp Jerzy (Pańkowski) (2016, s. 117-122).
} 
główną przyczynę owej sytuacji, car upatruje brak szkół, które posiadałyby odpowiednio wysoki poziom oraz brak kadry nauczycielskiej zdolnej do ich prowadzenia. Omawiany rozdział zawiera szczegółowe rozporządzenia wydane przez sobór w tej sprawie. Nakazuje on duchowieństwu tworzenie przy parafiach szkół, w których uczniowie, poza zdobywaniem elementarnych umiejętności takich jak czytanie i pisanie, uczyliby się także śpiewu. Nauczyciele zaś mieli obowiązek wychowywania młodego pokolenia w duchu moralności chrześcijańskiej (Gtawa XXVI, Stoglav", 1862, s. 121-122).

Co ciekawe, kwestie śpiewu cerkiewnego nie były dla cara obce, ponieważ uwielbiał on śpiewać w cerkwi, był kompozytorem i wykonawcą wielu utworów cerkiewnych. Dzięki temu, we wprowadzaniu reform dotyczących kwestii muzyki cerkiewnej, pomagał on swoim autorytetem (Gardner, 1978, s. 536; Parfent'ev, 1991, s. 77-78).

\section{Gtawa 31}

Gtawa 31 (Gtawa XXXI, Stoglav", 1862, s. 131-136) jest odpowiedzią na 26 carskie pytanie z I grupy i dotyczy czynienia znaku krzyża. Sobór Stu Rozdziałów odrzuca trójpalcowe (ros. trojepierstije) - przy którym należy łączyć kciuk ze wskazującym i środkowym, przyciskając do dłoni dwa pozostałe ${ }^{29}$. Jedynym prawidłowym sposobem czynienia znaku krzyża uznaje zaś dwupalcowe (ros. $d w o-$ jepierstije) - przy którym palec wskazujący i środkowy są wyprostowane, serdeczny i mały przyciśnięte są do dłoni kciukiem. Sobór utrzymuje starszy sposób czynienia znaku krzyża, co spowodowane było izolacją od Bizancjum po najeździe mongolskim. Niniejsza gława oprócz drobiazgowego wyjaśnienia konieczności żegnania się dwoma palcami, grozi, iż karą za naruszenie owego przykazu - jest przeklęcie (Gorskij, A. (red.), 1985, s. 438).

\section{Gtawa 41}

Gława 41 (Gtawa XL, Stoglav", 1862, s. 165-202) zawiera II grupę pytań cara (32) i przy każdym pytaniu, zamieszczona od razu została odpowiedź, czy też decyzja Soboru.

\section{- Pytanie X.}

Pytanie X reguluje, kiedy należy śpiewać psalmy: 136 - „Na rzekach Babilonu” oraz 134 - „Chwalcie imię Pań-

\footnotetext{
29 W taki sposób wierni Cerkwi Prawosławnej czynią znak krzyża obecnie. Przyp. aut. K.W. (ks.)
}

skie". Sobór postanowił (zgodnie z sugestią cara), że psalm 136 należy śpiewać trzy razy w roku - w niedzielę o synu marnotrawnym, w niedzielę seropustną oraz mięsopustną. W pozostałe niedziele należy śpiewać psalm 134 (Gława XL, Stoglav", 1862, s. 173-174). W dzisiejszej praktyce liturgicznej psalm „Na rzekach Babilonu” śpiewany jest razem z pieśnią „Chwalcie imię Pańskie” w trzy niedziele wspomniane przez Sobór Stu Rozdziałów.

\section{- Pytanie XI.}

Pytanie jedenaste jest uzupełnieniem 9 gławy, a dokładniej jej fragmentu dotyczącego sprawowania proskomidii. Mowa jest tutaj o wyjmowaniu cząsteczki za św. Jana Chrzciciela. Sobór postanawia, iż cząsteczka ta na ma być kładziona po prawej stronie agnca, i musi być mniejsza niż cząsteczka wyjmowana w intencji Przenajświętszej Bogurodzicy (Stoglav", 1862, s. 174).

\section{- Pytanie XII.}

Odpowiedź na pytanie XII reguluje sprawę wygłaszania rozesłania godzin kanonicznych, tj. przed rozpoczęciem Boskiej Liturgii. Sobór postanawia, iż we wszystkich świątyniach rozesłanie należy wygłaszać w królewskich wrotach, a następnie po otrzymaniu wybaczenia grzechów od wiernych kapłan rozpoczyna Boską Liturgię (Stoglav", 1862, s. 174).

\section{Glawa 42}

Gtawa 42 (Gtawa XLII, Stoglav", 1862, s. 202-210) odnosi się do śpiewania Allituja. Temat ten nie był poruszony w I czy też II grupie carskich pytań. Problem polegał na tym, czy Allituja śpiewać i czytać dwa, czy trzy razy. Sobór postanowił wygłaszać w następujący sposób: Allituja, Allituja, Stawa Tiebie Boże (Bočkarev, 1906, s. 210).

Niezwykle trudnym zadaniem jest przedstawienie kompleksowego zagadnienia i dorobku, jaki wniósł do nauki Cerkwi prawosławnej Sobór Stu Rozdziałów. Należy stwierdzić, iż Sobór Stu Rozdziałów osiągnął swój bardzo uniwersalny cel, poddając pod dyskusję wszystkie aspekty funkcjonowania Cerkwi na Rusi, w celu jej oczyszczenia z wszystkich niedoskonałości. Oczywistym faktem jest to, że nie wszystkie postanowienia były trafne, ale większość $\mathrm{z}$ nich - jeżeli faktycznie wprowadzone zostały do życia Cerkwi - była bardzo korzystna. Niestety historycy jednogłośnie potwierdzają smutny fakt niepełnej realizacji postanowień Stogława w funkcjonowaniu Cerkwi prawosławnej na Rusi. 


\section{Bibliografia}

Anchimiuk, Jeremiasz, abp. (2003). Reformy Patriarchy Nikona. W: J. Zieniuk (red.), Chrześcijaństwo Kościót Prawosławie (s. 14 -22). Białystok: Bractwo Prawosławne św. św. Cyryla i Metodego.

Bočkarev, W., A. (1906). Stoglav i istoriâ Sobora 1551 g. Ûhnov. [Бочкарев, В., А. (1906). Стоглав и история Собора 1551 2. Юхнов]

Bondaruk, K. (1987). Nauka o Nabożeństwach Prawosławnych. Białystok.

Borowik, H. (2001). W Cerkwi Prawosławnej. Białystok.

Boska Liturgia świętego ojca naszego Jana Chryzostoma. (2001). Warszawa: Warszawska Metropolia Prawosławna.

Bulgakov, M. (1870). Istoriâ Russkoj Cerkvi. (t. 6, Kn. I). Sankt-Peterburg. [Булгаков, М. (1870). История Русской Церкви. (t. 6, Кн. I). Санкт-Петербург].

Czasosłow. (1925). Warszawa.

Fediukina, H. (2014). Leksykon terminologii prawostawnej rosyjsko-polski, z cytatami z tekstów biblijnych. Warszawa: Warszawska Metropolia Prawosławna.

Florâ, B. N. (2010). Ioann IV Vasilevič. W: Pravoslavnaâ Enciklopediâ (t. XXIII, s. 628-641). Moskva [Флоря, Б. Н. (2010). Иоанн IV Василевич. W: Православная Енциклопедия (t. XXIII, s. 628-641). Москва].

Gardner, I. A. (1978). Bogoslužebnoe penie Russkoj Pravoslavnoj Cerkvi (t. I.). Jordanville. [Гарднер, И. А. (1978). Богослужебное пение Русской Православной Церкви (t. I.). Jordanville.]

Gorskij, A. (red.). (1985). Rossijskoe zakonodatel'stvo X-XX vekov. Zakonodatel'stvo perioda obrazovaniâ $i$ ukrepleniâ Russkogo centralizovannogo gosudarstva (t. II.). Moskva. [Горский, А. (ред.). (1985). Российское законодательство X-ХХ веков. Законодательство периода образования и укрепления Русского ичентрализованного государства (t. II.). Moskva.]

Gusejnova, Z., Perelešina, V., Starikova, I. (2005). Pesnopeniâ Vcenoŝnogo bdeniâ v russkoj monodijnoj pevčeskoj tradicii XVI-XVII vv. W: Pravoslavnaâ Enciklopediâ (t. IX, s. 675676). Moskva. [Гусейнова, 3., Перелешина, В., Старикова, И. (2005). Песнопения Вценощного бдения в русской монодийной певческой традиции XVI-XVII вв. W: Православная Енциклопедия (t. IX, s. 675-676). Москва].

Jakimiuk, M., Gabriel (Hagrioryta), hieromnich, Misiejuk, J. (red.). (2001). Katechizm Cerkwi Prawosławnej. Hajnówka.

Korobin, G., Mihajlova N. (1999). Ispravelnie bogosluženyh knig. Istoričeskij obzor za period s XV do načala XX veka, W: Bogoslužebnyj âzyk Russkoj Cerkvi. Istoriâ, popytki reformacii (s. 9-69). Moskva: Izdanie Sretenskogo monastyrâ. [Коробин, Г., Михайлова Н. (1999). Исправелние богослуженых книг. Исторический обзор за период с XV до начала XX века, W: Богослужебный язык Русской Церк- ви. История, попытки реформации (s. 9-69). Москва: Издание Сретенского монастыря.]

Lenczewski M. (1981). Liturgika. Warszawa: Chrześcijańska Akademia Teologiczna.

Liturgie Kościoła prawosławnego. (2001). Kraków.

Liturgija Ioanna Zlotoustago. (2001). Warszawa.

Ławreszuk, M., ks. (2009) Historyczny rozwój typikonu jerozolimskiego i jego współczesna rola, W: Elpis, 19-20 (32-33), 167-198.

Metallov, V. (1990). Očerk istorii pravoslavnogo cerkovnogo peniâ v Rossii. izdanie III. Moskva. [Металлов, В. (1990). Очерк истории православного церковного пения в России. издание III. Москва.]

Pańkowski, J., bp. (2016). Nie zaniedbuj w sobie daru łaski... Rozważania o kaplaństwie. Warszawa: Wydawnictwo Naukowe Chrześcijańskiej Akademii Teologicznej.

Parfent'ev, N. (1991). Professional'nye muzykanty Rossijskogo gosudarstva HVI-HVII vekov. Čelabin'sk. [Парфентьев, Н. (1991). Профессиональные музыканты Российского государства XVI-XVII веков. Челабиньск]

Sawicki, D. (2013). Idee „Świętej Rusi” i „Trzeciego Rzymu” i ich miejsce w nauczaniu staroobrzędowców pomorskich. Cerkiewny Wiestnik, 1/2013, 47-63.

Schmemann, A. (2001). Droga Prawosławia w Historii. Białystok.

Skaballanovich, M. (2004). Tolkovyj Tipikon. Ob"yasnitel'noe iz"yasnenie Tipika s istoricheskim vvedeniem. Moskva: Izdanie Sretenskogo monastyrya [Скабалланович, M. (2004). Толковый Типикон. Объяснительное изъяснение Типика с историческим введением. Москва: Издание Сретенского монастыря].

Stoglav". (1862). Kazan': v Tipografii Gubernskago Pravleniâ [Стоглавъ. (1862). Казань: в Типографии Губернскаго Правления.]

Trebnik. (2004). Kijów.

Ustawa z dnia 25 lutego 1964 r. - Kodeks rodzinny i opiekuńczy (Tekst ujednolicony ustawy). [online] http://isap.sejm.gov. pl/DetailsServlet?id=WDU19640090059, [9.04.2020]

Wilkiel, K., ks. (2019). Historyczne uwarunkowania Soboru Stu Rozdziałów. Elpis, 21 2019, 27-33.

Wołosiuk, W. (2003). Język cerkiewnosłowiański w monodycznym śpiewie cerkiewnym na Rusi. W: Chrześcijańskie dziedzictwo duchowe narodów stowiańskich. Białystok.

Želtov. M. (2001). Anafora. W: Pravoslavnaâ Enciklopediâ (t. II, s. 279-289). Moskva]. Желтов. М. (2001). Анафора. W: Православная Енциклопедия (t. II, s. 279-289). Москва].

Znosko, A., ks. (1975). Prawosławne Prawo Kościelne. Cz. II. Warszawa: Chrześcijańska Akademia Teologiczna. Warszawa. Znosko, A., ks. (2000). Kanony Kościoła Prawosławnego (t. I). Hajnówka. 